Title:

Gucci Inclusivity is the New Exclusivity

Authors:

CORRESPONDING AUTHOR - Alessia Grassi - University of Huddersfield, Queensgate, Huddersfield, HD13DH, UK - +44 (0) 1484471662 - alessia.grassi@hud.ac.uk

Dr Stephen Wigley - University of Huddersfield, Queensgate, Huddersfield, HD13DH, UK - +44 (0) 1484473707 - S.Wigley@hud.ac.uk

Received March 24, 2018; Revised April 24, 2018; Accepted June 6, 2018 


\section{Gucci Inclusivity is the Exclusivity}

High-street brands are aiming to generate inclusivity through the co-creation of their products; whereas luxury fashion brands have to seek inclusivity without endangering luxury product features, such as craftsmanship. Moreover, luxury brands are still experiencing difficulty in creating a relationship with the consumer fearing to lose control and the allure of exclusivity.

However, it is possible to identify a successful example of attempted inclusivity among luxury fashion brands: Gucci S.p.A. This paper aims to analyse Gucci's attempt to generate inclusivity through different activities that are not compromising the perceived exclusivity of the product, but on the contrary, they are an opportunity of brand value generation.

Data were collected through one semi-structured interview with the Gucci's CMO, two semistructured interviews with $2^{\text {nd }}$-year university students of fashion marketing, and one focus group with four final-year university students of fashion marketing. All data were analysed by applying thematic analysis, and the themes of engagement, and brand experience.

Findings suggest that Gucci's new exclusive inclusivity strategy incorporates a series of educational activities for selected groups of Higher Education students that provide an authentic insight into the brand. The evidence says that the strategy is appealing to Millennials and may be successful on the market.

Keywords: Inclusivity, Consumer Engagement, Co-Creation of Value, Luxury Brands, Exclusivity, Relationship Marketing. 


\section{Introduction}

Two distinguishing elements of a luxury product are its limited accessibility and its allure of perceived exclusivity. These two features are also one of the primary reasons why luxury brands have experienced difficulty in creating a relationship with their clients based on an authentic inclusivity and a two-way dialogue, where this dialogue has to be considered as a distinctive element of engagement and a powerful tool to create a deeper with the consumer. However, the fear of losing the allure that differentiates the luxury brands from other brands is stronger than the will to attempt activities aimed at enhancing inclusivity and dialogue.

Social media is a primary tool applied to building inclusive relationships with the public, and mainstream brands are seeking novel solutions for involving consumers in brand activities; for example, including the consumer in the process of designing or promoting the product, in turn inspiring brand image, customer loyalty and enhancing sales. Luxury fashion brands face the challenge to generate two-way dialogues with the consumers while simultaneously maintaining the allure of exclusivity and remaining committed to their business strategy of retaining control over all aspects of their activity (Moore \& Birtwistle, 2005).

Through secondary research based on literature review and a seminar led by the Chief Marketing Officer (CMO) of Gucci S.p.A., entitled 'What do you stand for' and dedicated to define authenticity, brand values, inclusivity, and engagement strategies according to the brand's vision; and through primary research based on a focus groups with four final-year university students of fashion marketing, an interview with two second-year university students of fashion marketing, and an interview with the CMO of Gucci, this paper explores Gucci's initial attempts to become an inclusive luxury fashion brand by examining the brand's implementation of novel initiatives within its wider marketing strategy. Specifically, the aim of this paper is to analyse Gucci's initiatives designed to generate among specific potential consumers a sense of inclusivity while maintaining the perceived exclusivity of the product. ${ }^{1}$

\section{Luxury Fashion Brands Exclusivity VS Consumer Engagement}

Luxury fashion goods are characterised by a number of elements including: high price combined with high-quality design and material; craftsmanship; and sophisticated communication strategies involving heritage and storytelling (Kim \& Zhang, 2015). However, the most important attributes of a luxury product are perceived exclusivity, and limited accessibility which together add allure to, and build customer desire for, the product (Catry, 2003; Phau \& Prendergast, 2000; Radon, 2012). As the luxury fashion market (and its consumers) has evolved, these defining characteristics have been threatened.

\footnotetext{
${ }^{1}$ This paper reports on the early stages of the analysis that is part of a larger Ph.D. study.
} 
While the concept of 'luxury' has become diffused during the 2000s and luxury products arguably made more widely accessible (De Barnier, Falcy, \& Valette-Florence, 2012), brands have enacted various strategies aimed at bolstering the perception of exclusivity, typically via tightly controlled promotion and product distribution (Moore \& Birtwistle, 2005), effectively creating distance between brand and consumer. Distance also enhanced by significant investments in stararchitects' projects of impressive retail stores where each floor represent a hierarchic level in the customer-brand relationship (Daye, 2009), and the staff is trained to interact with them by avoiding an excessive friendly attitude that is not always appreciated by the luxury consumer (Amatulli \& Guido, 2012; Fassnacht \& Scharwey, 2015). Yet, this strategy has been at odds with the desires of Millennials for distinctive products, memorable experiences, brand authenticity, and the creation of a relationship with brands based on a two-way communication (Giannachi et al., 2014).

Interaction, challenges, and engagement are the key bases to succeed in providing a significant experience to customers (Schmitt \& Zarantonello, 2013). Moreover, engagement is also considered as part of the process to generate brand resonance, the most desirable status for a brand and a potential provider for a deep and strong bond with the consumer (Keller, 2001). However, engagement should be considered not as a simple interactive feature of the experience provided (Keller, 2008), but as a tool to provide meaning (Kim \& Kim, 2014), as a two-way inclusive communication between brand and consumer that might lead to generate benefits for both the parts involved, such as new knowledge, and brands' values (Giannachi et al., 2014).

Mainstream brands in the mid- and premium fashion and sportswear sectors have applied cocreation and co-design initiatives in an attempt to coalesce selective positioning with consumer relationship (Adidas, 2017; Frow, Nenonen, Payne, \& Storbacka, 2015). However, this route is inappropriate for luxury brands due to the specificity of elements that define their products such as craftsmanship, archive-informed proprietary design and product quality, alongside their strategic orientation toward tightly controlling all aspects of the brand and product (Fionda \& Moore, 2009; Moore \& Birtwistle, 2005; Tynan, McKechnie, \& Chhuon, 2010).

Therefore, the dilemma facing luxury fashion businesses is to maintain perceived exclusivity while satisfying consumers' desire for authentic experiences of, and two-way communication relationships with, the brand (Gilmore \& Pine, 2002; Schmitt, 1999; Schmitt, Brakus, \& Zarantonello, 2015). In fact, businesses which successfully manage this problem, rather than losing the allure of exclusivity, may generate desire and loyalty for the brand, as well as enhance their image (Franzé, 2017; Kim \& Lee, 2016; Marzo-Navarro, Pedraja-Iglesias, \& Pilar Rivera-Torres, 2004; Triefus, 2017). Gucci's early efforts to this end may be interpreted as an attempt by a luxury fashion brand to become inclusive while maintaining the allure of exclusivity essential to brand positioning, and at a broader level indicative of a new paradigm for luxury brand marketing (McKinnon, 2017).

\section{Gucci S.p.A.}


Established in 1921, Gucci evolved to become a brand noted for influencing not only fashion trends, but also marketing and management practice in the luxury and premium sectors during the early 2000s under the leadership of Tom Ford (Moore \& Birtwistle, 2005). Since the appointment of Alessandro Michele as Creative Director in 2015, Gucci has implemented several innovative initiatives as components of its marketing and communication strategy aimed at initiating dialogue regarding the brand and its values with artists, influencers and consumers (Triefus, 2017). A number of these initiatives will be considered in this paper.

Firstly, \#GucciGram. This is an Instagram initiative where participants may create new artworks by reinventing classic pieces of art and merging them with the floral patterns of Michele's collections. Some of these works were commissioned to specific artists, while some others were spontaneously produced by Instagram users (Chayka, 2015). Two other successful initiatives emerged from Michele's interest in the creativity of the digital world, specifically Instagram (Triefus, 2017). The first was the creation of a capsule collection with the artist Gucci Ghost who co-opted the Gucci logo within his artwork initially on an unauthorised basis (Petrarca, 2016). The second initiative is the creation of street arts in collaboration with the Instagram artist Coco Capitán (Ahmed, 2017).

Alongside these specifically promotional-orientated initiatives, Gucci has sought to involve Millennials in strategic business decisions by establishing a 'shadow committee' of under-35-year olds informing corporate board decisions (Bain, 2017). These have been cumulatively aimed at endorsing the relevance of Gucci to Millennials, and been credited with inspiring the brand's notable recent commercial success.

Finally, another significant initiative that Gucci has enacted with the aim of generating relevance among younger, creatively-orientated consumers is a series of small-scale educational activities offered to fashion students: from sponsoring fashion degrees at the most prestigious fashion schools in Italy (Wallace, 2017), to launching a research lab with an Italian business school (Berezhna, 2017) and presenting industry insight seminars to students in Britain (Chatsworth House, 2017). The latter is the focus of this paper. This seminar was involving a small number of University students and it was entitled 'What do you stand for'. The seminar was dedicated to defining authenticity, brand values, inclusivity, and engagement strategies according to the brand's vision.

\section{Methodology}

Findings exposed in this paper are based on three main sources. The first data source is a semistructured interview with Robert Triefus, CMO of Gucci S.p.A. that took place during the seminar he conducted at Chatsworth House in October 2017. The second data source is a semi-structured indepth interview that involved two second-year university students of fashion marketing who volunteered to participate to the aforementioned seminar, which was part of a wider educational activity organised by Chatsworth House in connection with the exhibition 'House of Style' that was sponsored by Gucci. The last source is a focus group that involved four final-year university students 
of fashion marketing who were asked to attend the same seminar. All the students involved, in both the interview and the focus group, are European, in the age ranged that marketers define as Millennials, and they expressed more interested in luxury goods and items than others, even if at this point in time they cannot afford luxury purchases.

The main line of enquiry for the interviews and the focus group was based on two main concepts. The first concept was the engagement concept conceived as a two-way involving communication that might produce beneficial outcomes. The second concept was the idea that by experiencing a brand some feelings might generate from the experience.

The material retrieved from both the interviews and the focus group were analysed through a thematic analysis based on the two main concepts aforementioned. In particular, Gucci's CMO interview has been analysed looking for two specific keywords: two-way dialogue, and inclusivity. While, students' interview and focus groups have been analysed looking for three general themes: the opinion on the brand before and after the experience, the expectations towards the experience, the impact and the feelings generated by living the experience. Finally, based on the Gucci's CMO seminar where it was claimed that the brand is aiming to include people, and considering this seminar as a way to include people, particular attention for the word inclusivity was given also in the analysis of the students' interview and focus group. For the same reason, the idea of conducting a focus group and an interview with students that participated the seminar is based on the intention of understanding if the activities that the brand is implementing in its strategies (as explained in section 3 ) could be considered as successful strategies to consider inclusive a luxury brand without undermining the allure of exclusivity of its products.

\section{Findings \& Discussion}

\subsubsection{Gucci Interview Findings}

Based on the idea that engagement should be conceived as a 2-way involving dialogue intended for coproducing benefits, as explained in section 2, the main line of enquiry towards Gucci's CMO Robert Triefus was designed to better understand whether their initiatives are authentically designed to prefer a 2-way conversation over the idea of a conversation controlled by the brand. Especially, the seminar held by the CMO of Gucci was focused on authenticity, brand values, and the words engagement and inclusivity were constantly repeated. For this reason, the in-depth interview was mainly focused on the one single theme of a 2-way communication.

Findings and discussion derived from the aforementioned interview are as follow.

How is Gucci engaging in a 2-way dialogue that goes beyond the mere collaboration?

There is a number of opportunities to engage with people outside of the general commercial boundaries, said Mr. Triefus. When asked for specific examples, he cited the exchange of ideas regarding the products, a dialogue regarding the storytelling that the brand is narrating, or the simplest 
dialogue of being there to help the consumer with any problem that might occur and to discuss their satisfaction.

Why is it hard for some brands, especially luxury brands, to initiate a 2-way dialogue?

According to Mr. Triefus, the main reason why it is so hard for luxury brands to point at an inclusive strategy derives from two consequently reasons. First, it has always been one of the main characteristics of luxury brands, especially in fashion, to dictate the trend and the style; they have always imposed themselves and their idea of style upon the consumers. The second reason that is generating difficulty for some brands to initiate a sincere dialogue, and on some extent related to the first, is "the controls that luxury brands used to put in place to protect the aura of (exclusivity of) the luxury brand" and the fear that brands have to lose that feeling of control.

Why, according to Gucci experience, an inclusive 2-way dialogue is important?

There is a need for freedom today, according to Mr. Triefus, that is what is transforming the idea of imposing the brand in an old-fashioned strategy. According to his experience with Gucci and the different initiatives that they are implementing, at the beginning it feels risky to let go the control, but "when you open the doors, when you create the opportunity, it is actually incredibly empowering and enriching". The idea of including people external to the brand in the dialogue, gives the brand the opportunity of dipping into a larger basin of creativity "that it is out there and we can bring to life through what we represent".

What is the most important tool that allows Gucci to engage with a variety of actors?

The answer to this question was that social media, and the digital in general (their website, for example) is the main tool they have at their disposal to open a dialogue, and at this moment, it is at the very core of the brand strategy, and so perceived as the natural tool to exploit.

\subsubsection{Gucci Interview Discussion}

What derives from this brief conversation, and the quick glance to the latest brand's communication strategies, is reflecting the suggestions of the main experts with reference to inclusivity and engagement. It is noteworthy that Gucci, in the person of its $\mathrm{CMO}$, is able to consider the idea of an opening towards people as a stratagem to bring new life and inspiration to the brand, something that might go beyond the mere idea of selling the product. Obviously, as for any other firm, Gucci's final scope is to increase profit margin, however, they are apparently doing it in a less standardised way, they are attempting to take some risks, to explore and to innovate, and they are doing it with unconventional actors. This should be perceived as a shifting in the luxury paradigm, as a first step en-route for an opening of luxury brands towards inclusivity. Moreover, by thinking at the idea that engagement has to generate benefits for both the parts involved in the dialogue, letting people share their creativity its enabling Gucci to extract value for the brand, but at the same time is allowing the people involved to generate value for themselves by enhancing self-confidence and selfawareness - that finally can lead to a strength in loyalty towards the brand (Arnould \& Price, 1993; Harmeling, Moffett, Arnold, \& Carlson, 2017). Furthermore, in the transformative economy context, 
the enhancement of self-confidence and self-awareness could bring a person to live a transformative experience, a kind of experience that might lead to an even deeper bond with a brand (Arnould \& Price, 1993; Kozinets, 2002; Mermiri, 2009).

\subsection{Students' Experience \& Discussion}

With regards to an open dialogue and the generation of value that can derive from this dialogue, it is significant to listen to the voice of some students that had a first-hand experience with the brand during the seminar. The main line of enquiry for both the interview and the focus group was based on understanding expectations, after effect, and impact of experiencing a brand. This derived from the idea that experiencing a brand might generate loyalty towards it, as explained in section 2 . Hence, the enquiry attempted to understand the opinion that participants had regarding the brand before the experience, and the opinion they had after the experience, in the spirits to evaluate the possibility that they could become future consumers. The seminar that the students attended was a deep insight on Gucci's marketing strategies, branding and communication techniques. This insight allowed the student to realise how a career in fashion marketing, and communication and promotion might be. The students that were interviewed (or took part at the focus group) declared that they had not a specific knowledge of the brand before the event, except for the name, they were not aware of its specific image, products, and values. Moreover, the majority of the students interviewed have claimed that before the seminar they had quite a low opinion of the brand. "It's one of the luxury brands I knew the least about. [...] I thought a little bit lower of it, to be honest. I went there with the idea that I wanted to find out more about that. But definitely, I didn't think much of it before going" (2YS1). Finally, all the students claimed that, because of their knowledge of marketing strategies and the fashion industry, they were very sceptical towards the quality of the seminar and what they could learn from it, by expecting the seminar to be a brand advertisement more than an educational moment. They did not expect a brand such as Gucci to be willing to share specific insight and explanations on actual strategies applied by the brand. Strategies that the students were aware of being successful because of their studies. "I thought the talk would have been a little bit over my head [...] because Gucci is such a big brand, like Chanel or Dior, sometimes they're [...] above everyone else, to the point that they will explain a little, but not giving you everything'" (4YS3). "[ ...] is just the monogram printed everywhere. I wasn't really a fan, I wasn't really expecting much of it. [...] But, I founded it very interesting, and changed my perception of it. What the brand is doing, collaborating with people. [...] It is still 'up there' but it is more accessible now. That, I think, changed how I see it" (4YS2).

According to the interviewees, having the opportunity to concretely see how applying specific strategies and techniques is allowing a brand to successfully reach predetermined goals, made them feel more secure with regards to their career choices: "I wouldn't mind working for Gucci now" (4YS1) "Yes, that (the talk) confirmed my personal idea of working in marketing. The brand insight, the marketing insight [...] I just confirmed that" (4YS2). Moreover, being a small selected group of people that attended the event, made them feel part of an elite, able to gather an exclusive knowledge 
that nobody else was allowed to have, or at least with a deeper impact than reading similar content on books or websites. "One of my friends, she went a few days before me (to attend the seminar) and then when I posted on Instagram she went 'Oh my god, I was there' and we continued to talk about it" (2YS2). "All my friends do the same course (Fashion Promotion and Communication) but at Manchester, and they were asking me, saying that they have never gone on a trip like that. So, I felt like I was amazing telling them all about it" (2YS1).

It has been asked to the students to imagine a hypothetic circumstance where they encounter their favourite celebrity and they start a conversation with regards to Gucci. The question was if in that circumstance they would feel on a par with the celebrity after having attended the seminar. All the interviewees declared that, because the event gave them a specific insight and provide them of information they were unaware before, in this hypothetical scenario they would probably feel superior to the celebrity: "they are just wearing it because it is a designer brand and they can afford it (or they received it as a gift), but because I study fashion and now I know more about Gucci, I can actually talk about it, while they can just wear it" (2YS2). The idea of sharing specific information with regards to the brand has made the students feel empowered, and this sentiment might be a very strong link between consumers and brands (Harmeling et al., 2017).

From both the interview and the focus group it emerged that the idea of being included by the brand in an exclusive access to specific information is something very meaningful for students, especially when the piece of information is targeting specific students' interests such as marketing strategies and promotion activities.

All the students involved are part of the Millennials category, and as experts are continuing suggesting, Millennials appear more interested in experiences related to the product (or the brand) than in the product itself (McKinnon, 2017). To feel more confident towards their career choices and, on some extent, to feel transformed by the experience (Mermiri, 2009) is what made the difference for these students that did not hesitate to share their experiences on social media and with their friends, generating a spontaneous word-of-mouth. Moreover, some students declared that after having attended the event they changed their opinion regarding the brand and they would probably buy it now (if they could afford it). As previously hypotheses, the product itself is not losing that allure of exclusivity because of an inclusive experience, while the brand is enhancing its image and desirability by sharing its values and by opening to a wider audience.

\section{Conclusions}

It is widely known that luxury brands, especially fashion brands, are experiencing difficulties to connect with the consumer through a deeper and more meaningful dialogue. Arguably, Gucci is showing that starting a conversation with people might help a brand in engaging and creating a relationship with the consumer. 
However, all the inclusive activities that Gucci is implementing still appear exclusive to some extent. While the artists selected on social media for collaborations cannot be considered as mainstream artists, they have a substantial number of followers online, thus they can be considered as celebrities. Moreover, the educational activities that the brand is sponsoring are taking place in very exclusive universities, or they are hosted in luxurious houses for a small group of selected students. Therefore, all these examples suggest the idea that the brand's attempts appear more as a sort of controlled inclusivity than a real inclusivity.

However, even if the inclusivity is only a perceived inclusivity, it can have very positive effects on the brand. The students interviewed have lived the Gucci experience as an exclusive event. It is the exclusivity of the perceived inclusivity that has made them feel self-confident and self-aware towards their friends and their career choices, and because the experience has leveraged on their own knowledge of fashion and marketing, at the end they felt to have achieved something more precious and lasting than the satisfaction that derives from buying a product.

To conclude, the Gucci case can be seen as a successful attempt of an exclusive inclusivity. However, even if it is only a perceived inclusivity, it is possible to notice the positive effect that connecting with people could have on the brand image. A genuine inclusivity through less controlled initiatives might be an opportunity to enhance brand image towards Millennials, that group of potential consumers that most of the luxury fashion brands are aspiring to reach. Moreover, this type of initiatives might help luxury brands to return to a philosophy of value creation more than value extraction, without fearing to compromise the allure of exclusivity of the product.

\section{References}

Adidas. (2017). Strategy overview. Retrieved from https://www.adidas-group.com/en/group/strategyoverview/.

Ahmed, O. (2017, September). Coco Capitán: Gucci's young art star. Business of Fashion. Retrieved from: https://www.businessoffashion.com/articles/people/coco-capitan-gucci-young-artstar.

Amatulli, C., \& Guido, G. (2012). Externalised vs. internalised consumption of luxury goods: propositions and implications for luxury retail marketing. The International Review of Retail, Distribution and Consumer Research, 22(2), 189-207. doi: 10.1080/09593969.2011.652647

Arnould, E. J., \& Price, L. L. (1993). River magic: Extraordinary experience and the extended service encounter. Journal of consumer research, 20(1), 24-45.

Bain, M. (2017, October). Gucci has a "shadow committee" of millennial advisors. Quartz. Retrieved from: https://qz.com/1111798/gucci-has-a-shadow-committee-of-millennial-advisors/.

Berezhna, V. (2017, November). Gucci and Bocconi University to launch gucci research lab. Business of Fashion. Retrieved from: https://www.businessoffashion.com/articles/news-bites/gucci-andbocconi-university-to-launch-gucci-research-lab. 
Catry, B. (2003). The great pretenders: the magic of luxury goods. Business Strategy Review, 14(3), 10-17. doi: 10.1111/1467-8616.00267

Chatsworth House. (2017). Exclusive GUCCI marketing seminar for students - 5 October 2017. Retrieved from https://uolonlinestore.files.wordpress.com/2017/08/gucci.pdf.

Chayka, K. (2015). \#GucciGram. Retrieved from http://digital.gucci.com/gucci-gram/p/34.

Daye, D. (2009). The anti-laws of luxury marketing \#8. Branding Strategy Insider. Retrieved from: https://www.brandingstrategyinsider.com/2009/09/the-antilaws-of-luxury-marketing-8.html.Wd32hXB39OM

De Barnier, V., Falcy, S., \& Valette-Florence, P. (2012). Do consumers perceive three levels of luxury? A comparison of accessible, intermediate and inaccessible luxury brands. Journal of Brand Management, 19(7), 623-636.

Fassnacht, M., \& Scharwey, A. C. (2015). Social distance in luxury customer--salesperson relationships. In S. Bartsch \& C. Blümelhuber (Eds), Always Ahead im Marketing: Offensiv, digital, strategisch (pp. 431-483). Wiesbaden, Germany: Springer Gabler.

Fionda, A. M., \& Moore, C. M. (2009). The anatomy of the luxury fashion brand. Journal of Brand Management, 16(5-6), 347-363. doi: 10.1057/bm.2008.45

Franzé, G. E. (2017). Creating the ultimate luxury fashion customer experience. American Marketing Association. Retrieved from: https://www.ama.org/resources/Pages/creating-ultimate-luxuryfashion-customer-experience.aspx.

Frow, P., Nenonen, S., Payne, A., \& Storbacka, K. (2015). Managing co-creation design: A strategic approach to innovation. British Journal of Management, 26(3), 463-483.

Giannachi, G., Carletti, L., Sinker, R., Ward, R., Stack, J., Locatelli, C., . . . Benford, S. (2014). ArtMaps: Framing Public Engagement. Paper presented at the Nodem, Warsaw, Poland.

Gilmore, J. H., \& Pine, B. J. (2002). The experience is the marketing. (n.p.): BrownHerron Publishing.

Harmeling, C. M., Moffett, J. W., Arnold, M. J., \& Carlson, B. D. (2017). Toward a theory of customer engagement marketing. Journal of the Academy of Marketing Science, 45(3), 312-335.

Keller, K. L. (2001). Building customer-based brand equity: A blueprint for creating strong brands. (n.p.): Marketing Science Institute. Retrieved from: http://www.academia.edu/download/40863813/CustomerBasedbrandEquityModel.pdf

Keller, K. L. (2008). Strategic brand management: Building, measuring, and managing brand equity (1st, Global ed.). London: Pearson.

Kim, J., \& Kim, J.-E. (2014). Making customer engagement fun. Journal of Fashion Marketing and Management, 18(2), 133-144. doi: 10.1108/JFMM-04-2013-0050

Kim, C. E., \& Lee, J. H. (2016). Qualitative Study on the Benefit Sought and Brand Loyalty by Product Category of the Luxury Goods. International Journal of Costume and Fashion, 16(1), 17-35. 
Kim, J. H., \& Zhang, B. (2015). Attitude and Purchase Intent for Luxury Fashion Goods. International Journal of Costume and Fashion, 15(1), 19-37.

Kozinets, R. V. (2002). Can consumers escape the market? Emancipatory illuminations from burning man. Journal of Consumer Research, 29(1), 20-38.

Marzo-Navarro, M., Pedraja-Iglesias, M., \& Pilar Rivera-Torres, M. (2004). The benefits of relationship marketing for the consumer and for the fashion retailers. Journal of Fashion Marketing and Management: An International Journal, 8(4), 425-436. doi: $10.1108 / 13612020410560018$

McKinnon, A. (2017, November). Monetising millennials: What the corporate world thinks it knows about young people. The Guardian. Retrieved from: https://www.theguardian.com/media/2017/nov/16/monetising-millennials-what-the-corporateworld-thinks-it-knows-about-young-people.

Mermiri, T. (2009). The transformation economy. In Beyond experience: Culture, consumer \& brand (pp. 59-114). London: Arts and Business.

Moore, C. M., \& Birtwistle, G. (2005). The nature of parenting advantage in luxury fashion retailing: The case of Gucci group NV. International Journal of Retail \& Distribution Management, 33(4), 256-270. doi: 10.1108/09590550510593194

Petrarca, E. (2016, March). Who you gonna call? GucciGhost. WMagazine. Retrieved from: https://www.wmagazine.com/story/guccighost-gucci-alessandro-michele-fall-2016.

Phau, I., \& Prendergast, G. (2000). Consuming luxury brands: The relevance of the "rarity principle". Journal of Brand Management, 8(2), 122-138. doi: 10.1057/palgrave.bm.2540013

Radon, A. (2012). Luxury brand exclusivity strategies: An illustration of a cultural collaboration. Journal of Business Administration Research, 1(1), 106.

Schmitt, B. (1999). Experiential marketing. Journal of Marketing Management, 15(1-3), 53-67. doi: $10.1362 / 026725799784870496$

Schmitt, B., Brakus, J. J., \& Zarantonello, L. (2015). From experiential psychology to consumer experience. Journal of Consumer Psychology, 25(1), 166-171.

Schmitt, B., \& Zarantonello, L. (2013). Consumer experience and experiential marketing: A critical review. In N.K. Malhotra (ed.), Review of Marketing Research (Vol. 10, pp. 25-61) Bingley, England: Emerald Group Publishing Limited.

Triefus, R. L. (2017). What do you stand for?. Gucci CMO seminar at Chatsworth House. [Recording and Power Point slides].

Tynan, C., McKechnie, S., \& Chhuon, C. (2010). Co-creating value for luxury brands. Journal of Business Research, 63(11), 1156-1163.

Wallace, F. (2017, September). You can now do a university course majoring in Gucci. Vogue. Retrieved from: http://www.vogue.com.au/fashion/news/a+gucci+major+at+university+is+now+a+thing, 44331 . 